\title{
Social Investment Policies in Chile and Latin America: Towards Equal Opportunities for Women and Children?
}

\author{
SILKE STAAB \\ Research Analyst, United Nations Research Institute for Social Development (UNRISD), \\ Palais des Nations, Bureau D-217, 1210 Geneva, Switzerland \\ email: staab@unrisd.org
}

\begin{abstract}
Social investment ideas are increasingly permeating social and care policy-making in Latin America. In this article, I analyse a variety of instruments which have been used to 'invest in children' across a range of Latin American countries to then zoom in on Chile, where early childhood education and care have attained a prominent place on the welfare agenda in recent years. This policy interest materialised in 'Chile Grows With You', an integrated child development strategy whose title resonates strongly with the global narrative on social investment. Engaging with the programme's aim of creating 'equal opportunities from the cradle', I discuss the transformative potential and the limitations of childcare service expansion in a highly unequal context.
\end{abstract}

\section{Introduction}

Children have acquired a somewhat iconic status on the current welfare agenda. In part, this trend can be attributed to the specific way in which the interest in social policy re-emerged after decades of disconnect between the 'economic' and the 'social' to the detriment of the latter (Mkandawire, 2004). Markets are no longer believed to be sufficient for resolving problems of poverty and social exclusion, and there is a growing acknowledgement of the 'activating' role of social policy which through investments in human capital and lifelong learning can promote economic participation, poverty reduction and international competitiveness (Jenson and Saint-Martin, 2003). Against this backdrop, social spending on children becomes particularly attractive, as it is said to yield important 'returns' in terms of cognitive development and skill accumulation - which are expected to 'pay off' economically - both to the individual and the broader community at a later stage.

In the European context, this ideological shift has been captured by debates about the 'social investment state' (Jenson and Saint-Martin, 2006; Lister, 2003). This shift, however, is not confined to advanced industrialised economies. As 
Jane Jenson (2009) shows, social investment ideas have also entered postadjustment policy-making in Latin America, where concerns about persistent poverty, inequality and social exclusion have mixed with efficiency arguments about activation and investment. It is within this logic that certain state activities have become re-legitimated, and experimentation with a very heterogeneous set of 'new' social policies has taken place (Barrientos et al., 2008; Molyneux, 2008). As the first section of the article will show, regional policies targeted at improving the wellbeing of children have included cash transfers, nutritional programmes and informal daycare as well as more professionalised early education services.

Clearly, these efforts do not endorse equality - let alone gender equality as a value in its own right. Indeed, some authors have voiced concern that the greater targeting of social policies to children and young people gives gender equality issues short shrift (Jenson, 2008) and that future-oriented goals such as the creation of 'equal opportunities' or 'equality over the life cycle' have replaced the concern for needs and inequalities in the here and now (Mahon, 2002; Fawcett et al., 2004; Phillips, 2006). On the other hand, the 'return to social policy' (Razavi, 2007) and its concern for the future of children may open doors for gender demands as well. 'Investing in children' is concerned with care, a crucial and much neglected societal function whose costs - in terms of financial obligations, forgone earnings, career opportunities and entitlements to social insurance benefits - are largely borne by women. Greater attention to care means greater attention to an issue that shapes the experiences of many women, both at home and in the labour market.

This article argues that the extent to which social investment ideas can work to women's advantage depends largely on how they are translated into specific policy instruments at the national level. In the Latin American context, most of the current instruments aimed at relieving child poverty and investing in children are highly ambiguous in this respect, as they often rely on the (unpaid or poorly paid) work carried out by mothers or female community volunteers. This contrasts rather sharply with the recent expansion of professionalised public early childhood education and care (ECEC) services in Chile, which seems to be more promising from a gender perspective. The programme's emergence, scope, institutional rationale and 'fit' into the country's trajectory in social service provision are discussed in the second part of the paper.

While it is argued that the programme represents a major breakthrough in Chilean social and care policy-making, its potential and limitations of creating 'equal opportunities' for women and children in a highly unequal environment are discussed in the following two sections. The programme's focus on equality of opportunities rather than outcomes refers, on the one hand, to the opportunity of children for whom 'compensatory education' provided by public institutions will lead to a greater disconnect of their life chances from the income group they are born into. On the other hand, it suggests that women's opportunities 
are broadened, as they can enter the labour market on a more equal footing with men once some of the responsibilities for unpaid caregiving are socialised through public service provisioning. While it is too early to assess the success or failure of the programme in achieving these goals, the article is concerned with its design and prospects for reversing some of the gender and social inequalities through ECEC services. Whether the new programme will have lasting effects remains, of course, to be seen.

\section{Child-centred social investment in Latin America}

Across the Latin American region, 'investing in children' has taken diverse forms, including nutritional and health programmes, conditional cash transfers, the promotion of parenting skills and the expansion of a range of formal and informal care and educational programmes (Schady, 2006). This section will briefly discuss some of these approaches across a range of countries. The main objective is not to provide an encompassing overview, but to highlight - through a few examples how their focus on neo-liberal notions of 'co-responsibility' and 'co-management' limits the extent to which poor women's needs for greater economic security and autonomy can be addressed. ${ }^{1}$

In the area of social assistance, conditional cash transfer programmes have proliferated throughout the region, strongly promoted by multilateral organisations. The two largest and long-standing programmes in this area Mexico's Progresa/Oportunidades and Brazil's Bolsa Familia - have served as blue-prints, and by 2008 at least ten Latin American countries had initiated similar schemes. Cash transfers are targeted at the poor and conditional on compliance with requirements linked to children's health and education, such as regular health checks and school attendance, as well as the participation of caregivers in health and nutritional workshops. With few exceptions, benefits are channelled through women, usually mothers, who are in charge of fulfilling the conditionalities (Molyneux, 2007; Bradshaw, 2008; Serrano, 2005).

A number of evaluations have shown the positive effects of some of these schemes on child development, including primary and secondary school enrolment and attendance rates, improvements in food consumption and height, as well as school dropout rates and child labour (Perez Ribas et al., 2008). Only in Mexico are incentives set in ways that promote the school attendance of girls in particular in order to equalise the opportunities of boys and girls through access to educational endowments (Escobar Latapi and Gonzalez de la Rocha, 2008).

Whether the cash benefit empowers women and increases their autonomy vis-à-vis men in the same household remains a contentious issue. While an evaluation of the Mexican programme found that access to cash had increased women's voice in household decisions (Adato et al., 2000), for example, others 
have raised concerns about men withholding their financial contributions in households where the women receive the transfer (Armas, 2004; Bradshaw, 2008).

Conditional cash transfers certainly have the potential to support women in their role as caregivers, allowing them to purchase essential inputs for household survival. They do not, however, broaden their options beyond that role by giving them a more secure footing in the labour market, for example. By putting 'mothers at the services of the state' (Molyneux, 2007), conditional cash transfers bear the risk of discouraging men from assuming care-related tasks and overburdening women whose (paid and unpaid) inputs into household survival have both diversified and intensified in many developing countries (Chant, 2008).

A second concern is that the spending on cash grants may take the policy focus away from the need for long-term public investment in decent social and care services, which are less likely to translate into short-term electoral gains than cash transfers. Evidence from Brazil suggests that while cash transfers have increased as a share of public social spending over the last few years, investment in public services, including basic sanitation, housing and education, has stagnated or declined (Melo, 2007; Hall, 2008). While transfers and allowances may assist poor households pay 'user charges' and purchase goods for household survival, they do not substitute for the urgent need to strengthen the accessibility and quality of public care services. From a gender perspective, these services are more likely to create the basic conditions under which women can extend their economic and political participation beyond traditional maternalist models.

The concern for children, together with constrained social spending, has made family and community-based service provision attractive interventions. Since the mid-1980s, this has been the tendency in programmes aimed at improving child nutrition. Peru's Glass of Milk programme is one of the bestknown schemes in this area. Launched in 1983, it built upon the basis of popular grass-roots organising for collective provisioning during the time of crisis and retrenchment, using local 'mothers' clubs' and women's committees as key administrators. While participation in these popular initiatives fostered women's organising and provided them with access to training, education and health, the programme relied heavily on the unpaid work of female volunteers. Similar programmes were implemented throughout the region and continue to this day. A more recent example is Argentina's National Nutrition and Food Programme, implemented in 2003 as a response to the hike in food prices (Faur, 2009).

Other programmes have combined nutritional objectives with non-formal daycare. This is the case of Colombia's Community Nurseries Programme (Hogares Comunitarios de Bienestar). Targeted at low-income families, it promotes the creation of parent committees which select a volunteer mother from their community (madre comunitaria) to offer home-based daycare at her house. The volunteer mother receives some training and funds to adapt her house as well as a small stipend of around US $\$ 4$ per month per child paid by families. 
Almost identical programmes have been implemented in Bolivia, Venezuela and Guatemala.

With regards to early childhood education, an evaluation of the Guatemalan programme documented that caregivers allocate much less time to educational activities ( 6 per cent) than foreseen by the programme rules ( 23 per cent). Other problems identified by the study include insufficient training, as well as a scarcity of financial resources to purchase food and other supplies, which were seen as essential in terms of service quality (Ruel and Quisumbin, 2006).

The impact on women is less documented. In Guatemala, mothers who left their children in daycare were found to be younger, less educated, often single and living in more precarious working conditions than women in the control group (Ruel and Quisumbin, 2006). At the same time, however, they were more likely to have formal employment and earn higher incomes than mothers using alternative childcare arrangements. The volunteer mothers provide the services for 12 hours a day, five days a week, receiving US \$8 per child per month of which $\$ 5$ is paid by parents and $\$ 3$ by the government (Ruel et al., 2002). None of the daycare programmes outlined above has tried to incorporate men as caregivers.

In terms of entitlements, all of these programmes entrench existing gender inequalities in care and make women's access to social benefits and services largely dependent on their proof of commitment to family and community wellbeing. By dismissing the opportunity costs associated with unpaid care, the outlined approaches seem to endorse different logics for children - whose capabilities are invested in - and their mothers - whose responsibilities are increased with no equivalent reward in terms of rights and opportunities (Molyneux, 2007). At the same time, they fall short of delivering the kind of professionalised educational services necessary if 'social investment' in the human capital of children is to be taken seriously. This stylised inconsistency in women's and children's welfare is not inevitable. In the Nordic welfare states, for example, the universal provision of public childcare services has proven a powerful tool for promoting women's employment and child development alike. Here, egalitarian models of childcare provision were expanded both out of a commitment to gender equality and to children's rights, seeking to combine care and education in one system (Mahon, 2002). The extent to which synergies can be achieved today depends on how 'social investment' ideas and objectives are translated into concrete policy practice.

Over the last years, several middle-income countries (including Uruguay and Chile) have significantly expanded formal arrangements combining (professional) educational services and care, without demanding the high copayments in the form of women's unpaid care labour outlined above. Increasing female employment has been one of the rationales behind the expansion of publicly provided and publicly financed care services and the creation of synergies between early education (of children) and the provision of care services (for working parents, particularly mothers). These efforts - and their potential to 
broaden women's and children's opportunities - have received little scholarly attention so far.

Chile provides a case point for a recent and seemingly ambitious policy in this area. Interestingly, the Chilean government has decided to go for an expansion of public services for children under the age of four, rather than community-based solutions or subsidies to private providers, which represent common solutions in a series of other countries as different as Argentina, South Korea and Mexico (Faur, 2009; Peng, 2009; Staab and Gerhard, 2010). The following section analyses the programme's emergence, scope, rationale and 'fit' into the country's trajectory in social service provision. Considering that ECEC is a highly feminised activity, it will also look at the kind of employment that is created through the recent service expansion.

Given the extremely fast diffusion of cash transfer schemes, it is not impossible that childcare services provision will spread as a policy concern in the near future. It is thus worthwhile looking at the design of a pioneer initiative in the region. Since the Chilean programme is rather recent, a proper evaluation cannot be carried out in this article. Rather, the following analysis aims to tease out a series of threads to what may well be the beginning of a discussion about childcare service expansion in Latin America.

\section{'Chile Crece Contigo' and the recent expansion of ECEC services in Chile}

Since the return to democracy in 1990, early childhood education and care have gradually acquired prominence on Chile's social policy agenda, and several mechanisms have been put in place to increase coverage, promote equal access and improve quality (Umayahara, 2006). These efforts gained momentum under the Lagos administration (2000-2006), but were concentrated on the transitional levels: that is, the two years before the start of primary education. The institutional structure and coverage for children under the age of four remained underdeveloped.

When Michelle Bachelet took office in 2006, institutional care for younger children became one of her administration's social policy priorities. With Chile Crece Contigo ('Chile Grows with You') - an integrated child protection strategy launched in October 2006 - the government committed to a significant expansion of quality crèches and kindergartens, particularly for children from low-income families (Mideplan, 2007). ${ }^{2}$ By early 2009, this commitment had been transformed into a legal entitlement to a crèche and kindergarten place for children from low-income families.

Child-centred social protection can be seen as part of larger changes in Chile's social policy regime. Since the early 2000 s efforts to expand social protection, to improve access to social services and to strengthen social rights have featured 
prominently on the country's social agenda. The focus is no longer exclusively on poverty. After a remarkable reduction in poverty rates over the last two decades, policy efforts now increasingly aim at reducing social exclusion and inequality. Important reform processes have been underway in the area of social insurance (unemployment, pensions), health and education. These changes, however gradual, are slowly doing away with some features of the market-based model of social provisioning, which the country pioneered and buttressed under authoritarian rule. Some have even argued that Chile may be approaching a 'point of inflection' (Illanes and Riesco, 2007).

In order to increase the availability of crèches, kindergartens and preschools, a clearer division of labour among the institutions involved in the provision of ECEC services was envisioned. While the Ministry of Education would promote pre-schooling for the older age groups ( 4 and 5 years) through the traditional channel of subsidising municipal and market providers, the expansion of services for the younger age group $(\mathrm{O}-3)$ would take place through two different institutions: the National Council of Kindergartens (Junta Nacional de Jardines Infantiles, JUNJI), a government body linked to the Ministry of Education; and Fundación Integra, a private non-profit foundation forming part of the Presidency's network of foundations whose activities are almost entirely financed through public monies.

It is worthwhile exploring this recast of the institutional framework in greater detail. Pre-school education for four- and five-year-olds has been considered part of the educational system since 1990, and coverage has increased steadily from 43 per cent in 1992 to 76 per cent in 2006. ${ }^{3}$ The relatively broad coverage in this age group meant that the institutional framework was already firmly in place. Indeed, it mirrors the primary and secondary educational system, which was decentralised and opened up to private sector participation under military rule (1973-1989). Pre-school coverage is dominated by purely public schools (30 per cent) and subsidised private schools ( 36 per cent), which receive the same government subsidy per student. Twelve per cent of enrolment is absorbed by purely private providers, which finance their activities through fees. The remaining 20 per cent are enrolled in centres run by Integra and JUNJI. As in the rest of the educational system, there is a clear segmentation along the lines of household income with respect to coverage and the type of institution children attend. While the richest quintile sends 94 per cent of children from this age group to pre-school - half of which are enrolled in private schools - coverage in the first quintile is 81 per cent and largely concentrated in public institutions.

The embeddedness of pre-schools within the educational system may lead to a greater recognition of pre-school services as an educational measure. At the same time, however, it is likely to suffer from the structural constraints associated with a system which was shaped and buttressed under authoritarian rule and is still highly segmented. Public schools absorb more than half of the 
country's poorest students, while private schools cater for the wealthiest segment. According to the 2006 household survey, around two thirds of students at public secondary schools came from the two lowest income quintiles, while only a fraction of students were from the highest income quintile. The opposite is true for (unsubsidised) private schools, where three quarters of students come from the richest quintile. Furthermore, a large proportion of private schools receive subsidies from the state. There is an 'equal treatment' policy of public and subsidised private schools inherited from authoritarian rule, which impedes the allocation of additional resources to public schools by the central government, and has been claimed to be responsible for the deterioration of public schools (Riesco, 2007). ${ }^{4}$ The type of school children attend has important impacts on a set of variables, including test results for university entry, years of education, employment in manual versus non-manual work and hourly salary (Helgø, 2002; Matear, 2006). Attempts to strengthen the public system have stalled against economic and ideological opposition in Congress thus far.

Turning to the younger age group, we find that until 2006 coverage of twoand three-year-old children was low, and pretty much insignificant for children under the age of two. Arguably, this increased the room for manoeuvre for shaping the institutional landscape in which services would be provided. Against broader global trends to outsource childcare provision to market and non-profit providers, and the legacy of the country's own educational system then, the government used this leeway to strengthen the role of public institutions, while avoiding subsidies to market providers.

The recent expansion of public crèches and kindergartens for children from the age of three months up to four years is taking place almost exclusively through JUNJI and Integra, both of which are managed and funded by the central government. This does not mean, however, that there is no space for market provision or that Chile is moving towards universal public care services. Quite to the contrary, the new institutional framework initially urged JUNJI and Integra to target their efforts to children from the first two income quintiles or those representing other features of 'vulnerability' for whom ECEC attendance is free of charge. The underlying assumption here is that better-off families will be able to purchase and pay for services from market providers. As I will show in the following section, this assumption is likely to be problematic with regards to middle-income households. ${ }^{5}$

Looking at enrolment rates by income quintile, however, we find that the picture is more complex than that. In fact, centres operated by JUNJI and Integra absorbed an important share of nought- to three-year-old children from all but the richest quintile in 2006. Together, both institutions account for more than two thirds of enrolled children from the first and second quintile, but still absorb an impressive share of children from the third (61 per cent) and the fourth quintile (45 per cent). Children from the richest income quintile are concentrated in 
private daycare (6o per cent). I will return to the implications of this finding below.

Since 2006, the number of public crèches for children under the age of two has increased significantly. According to official sources, their number has more than quadrupled from around 700 in late 2005 to 3,000 by the end 2008 . The number of places in public crèches for nought- to one-year-old children has risen from around 14,000 in 2005 to 61,000 in 2009 . It is estimated that 85,000 public places for under two-year olds will be available across the country by the end of 2010 (Ministerio de Hacienda, 2009).

These developments have meant a major increase in government spending allocated to ECEC. The combined budget of JUNJI and Integra was around $\mathrm{CH} \$ 160$ billion (US $\$ 300$ million) in 2007 , corresponding to 5.5 per cent of the education budget (Ministerio de Hacienda, 2008a). Between 2005 and 2008, ECEC spending grew by 250 per cent and was further increased for 2009 in order to finance the construction of new crèches and the operation of the existing ones (Ministerio de Hacienda, 2008b). This is a significant financial commitment by the state. ${ }^{6}$

Early childhood education and care is associated with a rather clear occupational profile and formalised training and educational requirements. Indeed, ECEC teachers and educators are required to have a five-year university degree in early education (educadores de párvulos). Support staff are required to have a technical degree in early education from an accredited institution (técnico asistente de párvulos). These requirements have been kept in place for the younger age groups covered by newly created crèches and kindergartens.

The overwhelming majority of early childhood educators are women (JUNJI, 2008) and their salaries are among the lowest in the educational sector, which is already known for low wage levels (Riesco, 2007). Professional pre-school educators who graduated in 2005 and 2006 earned an average $\mathrm{CH} \$ 360,000$ (around US \$650) in their first year (around 20 per cent less than primary teachers), a very low amount when compared to graduates in professional careers of similar duration, both care-related and non-care-related. ${ }^{7}$ After five years, the average salary of early childhood educators who had graduated in 2000 and 2001 increased by only 11 per cent, showing that neither higher education nor work experience is particularly valued. ${ }^{8}$

JUNJI workers are public employees, and their salaries are negotiated alongside salaries for other public sector workers. Around three quarters are employed on a fixed-term basis (contrata), while the remaining staff have permanent posts (planta). According to the Ministry of Finance, JUNJI had not resorted to self-employed staff in 2006 (Ministerio de Hacienda, 2008a), a practice which had become common in the Chilean public sector. Nevertheless, there were fears among workers that the expansion could lead to an increased 'outsourcing' of tasks (such as food preparation) to subcontracted providers (La Tercera, 2006). 
Another concern raised by Integra employees is their discrimination in pay and benefits vis-à-vis their colleagues at JUNJI, particularly now that they both form part of the same government programme. Although most Integra workers have open-ended contracts (Ministerio de Hacienda, 2008a) - potentially a sign of some degree of job stability - they are not considered public employees. According to a study carried out by the Ministry of Education, Integra workers earn between 11 and 50 per cent less than their colleagues at JUNJI (La Nación, 2008) and lack specific benefits and bonuses related to geographical location and years of service. This issue has been endlessly delayed since the (re)founding of the institution in 1990, and Integra workers have been organising around this double standard for years. ${ }^{9}$

Regarding working conditions, there is evidence that crèches and kindergartens run by Integra and JUNJI are understaffed, and that this situation is more severe in Integra establishments. In 2006, less than two thirds of JUNJI's centres and less than half of Integra's complied with the Ministry of Education's staff coefficient, which is already pretty low. Turnover rates among staff are high at Integra (around 30 per cent), but relatively low (less than 3 per cent) at JUNJI. Integra, in turn, seems to do much better at providing training to its employees, with both the share of employees who received training and the average hours of training in 2006 being considerably higher than at JUNJI (Ministerio de Hacienda, 2008a). The training indicators may also reflect a greater need for training among Integra staff due to its lower level of professionalisation.

\section{'Investing in children': the problem of equal opportunities in an unequal world I}

The recent expansion of ECEC services coincides with a growing interest in ECEC in Latin America as a form of particularly 'efficient' social investment. In the Chilean context and relying on the concept of 'equal opportunities' for children from different social backgrounds, it has also been framed as a means of fighting persistent inequality which - after the remarkable reduction in poverty rates over recent decades - has come to constitute the bête noire of the country's social record.

Clearly, it is too early to draw conclusions from the impact of Chile Crece Contigo on children's opportunities. Nevertheless, it is worthwhile analysing some of the policy's potential and prospects. The challenge to reach a greater number of young children from low-income households remains, and the evaluations of the 2009 household survey will give a first indication of how the policies implemented since 2006 have paid off. Apart from access, however, the degree to which social inequalities can be redressed through public provision of ECEC services will depend to a great extent on how the programme addresses three key issues: namely social selectiveness, quality and systemic integration of ECEC services. 
The first issue is related to the limitations of targeting and welfare pluralism in achieving greater social equality. Assuming that the application and consequent tightening of the target mechanism are intended (and feasible), middle- and upper-income households would be gradually 'excluded' from public ECEC provision, obliged to turn to - yet-to-be expanded - private for-profit solutions and pay market prices for their childcare needs. This is likely to leave an important share of the middle-income groups stranded, as households might not have the financial means to turn to market-based solutions and opt for familialised care, restricting the options and opportunities of both women and children who belong to this income group.

What is more important, however, is that targeting can lead to segmentation, with important implications for service quality. 'Perfect' targeting of public ECEC would imply that the poorest 40 per cent attend public institutions, while the other 60 per cent have to turn to commercial ECEC services. As the previous section showed, this is not the case so far. Indeed, segmentation within the emerging system of early childhood education and care for the very young is less severe than in the primary and secondary educational system (Montt et al., 2005).

It is not yet clear what path the programme will take with respect to targeting versus universalism in the future. Efforts could be 'targeted' at the lower-income quintiles in order to increase equity within the existing model of ECEC service provision, and then be expanded to include children from middle-income groups. Narrow targeting, in contrast, is known to compromise quality as 'benefits meant exclusively for the poor often end up being poor benefits' (Sen, 1995: 14). ${ }^{10}$ This would seriously compromise the intention to 'level the playing field' for children from low-income families.

Narrow targeting also tends to be problematic for political and financial reasons. Research on advanced capitalist countries suggests that the sustainability of redistributive policies depends greatly on the backing of middle-income groups. Following this logic, a broader coalition of people who reap direct benefits from public social and care services is more likely to lead to redistributive and financially viable services of equal quality, because it fosters the 'willingness to pay' through taxation and the 'willingness to stay' in public schemes among wealthier segments (Korpi and Palme, 1998). In contrast to the narrow targeting to the poor or extremely poor observed in most cash-transfer, subsidy, waiver or exemption schemes, the targeting mechanism of Chile Crece Contigo is already rather broad: public crèches and kindergartens are open and free of charge for 40 per cent of households, instead of only reaching out to households below the poverty line (13.7 per cent) or in extreme poverty (3.2 per cent). Furthermore, while Chile Crece Contigo is not universal, a law was passed in Congress in early 2009 which defines the right to a crèche and kindergarten place for the target group. This increases the chance of continuity in the face of a government 
change, which effectively took place in early 2010. ${ }^{11}$ A first step towards reaching out to middle-income groups was made in the process, when Congress decided to extend benefits to the third quintile from 2011 onwards. In the long run, turning ECEC services into more universal ones would reduce segmentation and social stratification. Whether the Chilean programme can move further towards this goal will depend on the extent to which financial backing, service quality, professionalism and - very importantly - political will can be maintained.

The law that institutionalised Chile Crece Contigo (and therewith the right to full-day public childcare for working mothers' children) has been approved almost unanimously by members of Congress and Senate independent of party affiliation. This seems like a novelty in a political system with two large semiconfessional parties within which conservative views about women's place in society still prevail (Macaulay, 2006). That Chile Crece Contigo managed to foster such widespread support may well have to do with its child-centred frame. Including a crèche component (which challenges conservative ideals of family care) in a broader programme aimed at child wellbeing may have encouraged conservatives' support, or at least made it more difficult to justify opposition. Similarly, the 'investment' logic may have appealed to those who traditionally oppose increases in public spending.

The third concern is related to the lack of systemic integration of ECEC. Even in a more homogenous and universally accessible system, the creation of 'equal opportunities from the cradle' - one of Chile Crece Contigo's slogans is ambitious at best, as the translation of 'opportunities' into 'outcomes' is mediated by institutional and social arrangements other than childcare services. Expanding public ECEC is certainly not enough to 'level the playing field', as long as the rest of the educational system remains unchanged. For however much a child may have been stimulated during its first years of life, it will still face the dual system of primary and secondary education (referred to above and where quality is heavily dependent on the family's income), let alone the obstacles for accessing higher education resulting from high fees in both private and public universities. $^{12}$

\section{'Investing in women': the problem of equal opportunities in an unequal world II}

Social investment thinking is not confined to children as 'citizen-workers of the future' (Lister, 2003). Leading social investment thinkers have put forward productivist arguments for social policies vis-à-vis women as a 'massive untapped labour reserve' (Esping-Andersen et al., 2002) that needs to be activated as a means of reducing welfare dependency and poverty risk among low-income and/or single-earner families, as well as increasing the sustainability of social security 
systems. In a developing context, 'investing in women' has long been promoted by multilateral organisations as a strategy to foster efficiency and economic growth (Jackson, 1996; Razavi, 1997). A recent example of this trend is a Chilean report co-edited by the World Bank, the national women's machinery SERNAM and the Inter-American Development Bank (2007) entitled 'How to capitalize Chile's economic potential through the expansion of work opportunities for women'.

While growing attention to women and gender issues is a welcome trend, there have been concerns about the way these issues have been framed and addressed within instrumentalist approaches to gender equality. In particular, feminists have been worried about gender equality taking the backseat, when generalised aims, such as alleviating poverty or increasing welfare, become dominant (Razavi, 1999). More recently, concerns have been raised about the 'feminisation of responsibility and obligation' (Chant, 2008) through poverty reduction strategies, within which women are increasingly responsible for both the economic sustenance and social reproduction of their families.

As we have seen, many child-centred policies rely on women's unpaid labour, potentially restricting their ability to engage in paid work. 'Investing in women', on the other hand, often contains the implicit expectation that (poor) women perform paid work in order to lift their households out of poverty: by themselves if single or as 'second earners' if coupled. Together with the persistent neglect of unpaid care performed by women as well as increasingly precarious employment patterns, this expectation risks generating an ever-increasing demand on women's time.

Chile Crece Contigo is an interesting policy in this respect, as it represents an explicit offer by the state to partly de-familialise childcare for younger children, thus relieving women of some of their unpaid care responsibilities, potentially enhancing their ability to engage in paid employment. Furthermore, the policy challenges the ideal of unpaid, family-based childcare performed by mothers. Although this has not been stated as an explicit aim, the government and public institutions have engaged in a powerful communications strategy that promotes institutional childcare as enabling mothers to work, but more importantly as being good for children. Stressing the benefits of institutional care for children has the potential of liberating women from 'the moral predicament between working and caring' (Kremer, 2006). This is particularly important in a country like Chile, where female labour force participation has historically been low, and conservative forces, including the Catholic Church, strongly influence gender and social norms.

The expansion of ECEC services has featured prominently in Bachelet's speeches as one of the four transformations that her administration wants to move forward. Although presidential discourses mention childcare services as a means of facilitating women's labour force participation, they essentially focus 
on its value as an educational policy. ${ }^{13}$ The careful calibration of professional and motherly concern is well captured in the following extract:

You have heard me say this many times and I have said that - as a woman, as a mother, but also as a paediatrician - I am convinced that initial education is fundamental, that all the efforts in primary, secondary and later, of course, tertiary education won't be enough if we arrive late. And one way to be on time is to start at the youngest age. Therefore, and because we fight against inequality as of the cradle and we give mothers the opportunity to work, we will vigorously continue the crèche programme. (Bachelet, 2007)

The government has also made sure that media attention is drawn to the provision of childcare by staffing inaugural ceremonies with high-profile politicians and government bureaucrats. In addition, both the Director of Fundación Integra and the Vice-President of JUNJI, have published an important number of editorials in virtually all of the country's large newspapers on the benefits of expanding ECEC.

Thus, both on the practical and the symbolic level, the recent expansion of public childcare can be seen as an improvement for women, especially poorer women who cannot turn to market-based childcare solutions. From a gender equality standpoint, however, several caveats have to be mentioned. For, as desirable and positive the expansion of childcare is for women, it does not lead to equal opportunities by and of itself.

First, the commodification of care through public and private ECEC services has not resolved its under-valuation, or the fact that it is carried out predominantly by women. As this article has shown, in Chile (as elsewhere) paid institutional childcare remains largely a woman's job. As the previous discussion of ECEC employment showed, working conditions and wages of early education and childcare workers are a mixed bag. ECEC staff are publicly employed, well organised and increasingly mobilised for improving their situation; but they face significant disadvantages $v i s-\grave{a}$-vis professions that require similar educational levels.

A second concern is the absence of men from policy debates around unpaid care work. Since it is hardly possible (nor particularly desirable) to commodify all unpaid care work, a huge amount of it remains to be done even when full-time quality ECEC services are available. Indeed, even in a 'women-friendly state' like Sweden, the unequal sharing of unpaid care work has remained a problem (Hobson, 2006). In Chile, there has been little improvement in public policies aimed at a more equal intra-household division of caring labour. The entitlement to paid leave in order to care for sick children has been extended to fathers (1993), but maternity leave remains short and is still restricted to mothers. Since 2005, fathers have been entitled to four days of leave after childbirth: a regulation that may have some symbolic value but falls short of substantially changing gendered norms and practices in childrearing. 
Last but not least, whether recent policy innovations will work for gender equality depends to a great extent on the kind of employment opportunities the country's growth model generates for women and how they fare in the labour market vis-à-vis male workers. The current situation does not inspire too much confidence: the gap in male and female participation rates is significant; women are overrepresented in low-productivity sectors; and a sizeable gender gap in earnings works to women's disadvantage. Unemployment remains higher among women than men, indicating that women's expectations still clash with discrimination and a lack of opportunities in the labour market. In this sense, childcare policies remain disembedded from the larger macro-economic context. They enable women to compete on a more equal footing in the labour market, but do not question the kind of jobs available.

Efforts to recognise unpaid care activities and to redistribute them more evenly between families and the larger society must therefore be accompanied by more gendered labour market policies. Besides the provision of childcare services, such policies would include the promotion of women's participation in stable and productive employment, the enforcement of anti-discrimination laws, and the investment in training opportunities (Mesa-Lago, 2008).

\section{Final remarks}

As this paper has shown, the expansion of public childcare services represents a major breakthrough in Chilean social policy. It implies a substantial shift of responsibility from families to the state, with the potential of enabling mothers to participate in other activities such as income-earning or organising. Both at the practical and symbolical level it challenges the idea that childcare is a private responsibility to be carried out by women at home, and thus represents an important shift in social policy thinking that can undoubtedly work to the advantage of women. Within the larger context of the country's welfare trajectory, it constitutes a recasting of state-market relationships and a departure from the patterns of privatisation and pluralism in social service provision which have been dominant since authoritarian rule. The decision to go for public social services strengthens the labour market position of non-household caregivers, creating 'real' employment rather than 'voluntary' or 'community-based' work.

These encouraging insights notwithstanding, the programme also illustrates the limitations of social investment-driven policies with respect to gender and social inequalities. It is clear that 'equal' access to ECEC services, however professionalised, will not translate - ceteris paribus - into equal opportunities, let alone outcomes, for children from low-income families. Besides the lower educational background of their parents, children from low-income families face serious obstacles in accessing the kind of secondary and higher education available to their affluent peers. Accessible, affordable and professional early education is 
thus an important investment in the opportunities of children. Whether they are sufficient to achieve their equalising goal under the conditions of extreme income and social inequality we encounter in the Chilean context remains yet to be seen.

The availability of professional childcare services which are promoted as being 'good' for their children's future will certainly make it easier for mothers, especially those who cannot afford private care services, to engage in employment or other activities. But again, obstacles to equal opportunities in the labour market and other areas of public life go beyond women's care responsibilities. Gender discrimination in hiring and wage policies is a crude reality in the Chilean context (as it is elsewhere) and the country's economic model is not exactly known for creating decent employment for women. As such, the provision of ECEC services does not challenge the currently dominant concepts of social policy as a tool for promoting and enhancing the macroeconomic model already in place. However, and for the reasons outlined earlier, it constitutes a rather progressive measure within this conception of social policy and among other social investment-led policies in the region.

An important issue that remains to be explored in this context are the mechanisms through which global ideas about social investment translate into specific policy practice at the national level and under what conditions they are likely to produce beneficial outcomes for women. If, as Jane Jenson (2009) has argued, the global diffusion of social investment ideas is facilitated by the relative ambiguity of their meaning, then they can surely be used by different policy entrepreneurs to lobby for different policy outcomes. How are global social investment narratives seized, reinterpreted and challenged by domestic actors and institutions in order to propose or shape care policies in different contexts? Why do they generate or fail to generate significant commitments to social and gender equality (both in terms of resources and policy design)? The exploration of issues such as institutional legacies, party competition, the strength of (women's and other social) movements, as well as the influence of multilateral organisations and donors, would be interesting starting points for exploring these questions.

\section{Acknowledgements}

The author wishes to thank Elena Gaia and Shahra Razavi for valuable comments on previous versions of this paper. Helpful feedback was also provided by two anonymous reviewers.

\section{Notes}

1 These ideas became increasingly popular with the rise of the new poverty agenda and targeted assistance programmes focused on how the poor could be transformed into 'active participants in meeting the costs of development' (Molyneux, 2008: 784). 
2 Chile Crece Contigo includes a range of other measures aimed at the protection and wellbeing of children. In the following I will restrict my analysis to the component of institutional childcare service provision.

3 These and all the following numbers are the author's calculations based on 2006 Household Survey Data (Mideplan, 2006).

4 The public primary and secondary school system deteriorated during the 1980s, when public educational spending suffered a drastic decline from which it still has not recovered entirely. With the return to democracy, the public budget for education has increased consistently, but the funding mechanism for schools (per student) has remained. As most of the new enrolments have been concentrated in private subsidised schools (due to the poor quality of underfinanced public schools), they have received a disproportionate share of the newly allocated government funds between 1990 and 2003 in addition to which they can charge supplementary fees from families (Riesco, 2007).

5 Due to the extremely unequal income distribution, the average income of the middleincome groups (third and fourth quintile) is much below the average per capita income (ECLAC, 2008).

6 By comparison, Chile Solidario, the Chilean cash-transfer programme, had a budget of around $\mathrm{CH} \$ 78$ billion (US $\$ 130$ million) in 2007 (Ministerio de Hacienda, 2007).

7 Nurses, accountants, construction, chemical and industrial engineers earn between $\mathrm{CH}$ $\$ 620,000$ and $\mathrm{CH} \$ 1,111,000$ (based on data from Futuro Laboral, www.futurolaboral.cl). All salaries are gross.

8 Experience rewards better in accounting ( 36 per cent) and particularly so in engineering professions (60-9o per cent).

9 Fundación Integra's predecessor, FUNACO - a charity founded by Augusto Pinochet's wife in 1975 - operated with staff from Minimal Employment Schemes, implemented under military rule to combat unemployment. Participants served in public institutions and their work was considered unskilled and unproductive, with salaries significantly below the minimum wage (Buvinic, 1996).

10 An argument going back to the work of Richard Titmuss.

11 The governing coalition Concertación lost the presidential elections in early 2010, making way for the first right-wing government since the return to democracy 20 years earlier.

12 As the latest household survey shows, university education is still a privilege of upperincome quintiles: while half of the students from the highest quintile attend university, the rates in the three lowest quintiles are well below the 28 per cent average $(14,17$ and 24 per cent respectively).

13 Based on Bachelet (2006, 2007, 2008).

\section{References}

Adato, M., De la Biere, B., Mindek, D. and Quisumbin, A. (2000), The Impact of PROGRESA on Women's Status and Intra-Household Relations, Washington, DC: International Food Policy Research Institute (IFPRI).

Armas, A. (2004), Redes e institucionalización en Ecuador: Bono de Desarrollo Humano, Santiago de Chile: Economic Commission for Latin America and the Caribbean (ECLAC).

Bachelet, M. (2006), Mensaje Presidencial 2006, 21 May.

Bachelet, M. (2007), Mensaje Presidencial 2007, 21 May.

Bachelet, M. (2008), Mensaje Presidencial 2008, 21 May.

Barrientos, A., Gideon, J. and Molyneux, M. (2008), 'New developments in Latin America's social policy', Development and Change, 39: 759-74. 
Bradshaw, S. (2008), 'From structural adjustment to social adjustment: a gendered analysis of conditional cash transfer programmes in Mexico and Nicaragua', Global Social Policy, 8: 188-207.

Buvinic, M. (1996), Promoting Employment among the Urban Poor in Latin America and the Caribbean: A Gender Analysis, Geneva: International Labour Organization (ILO).

Chant, S. (2008), "The "feminisation of poverty" and the "feminisation" of anti-poverty programmes: room for revision?', Journal of Development Studies, 44: 165-97.

Economic Commission for Latin America and the Caribbean [ECLAC] (2008), Social Panorama of Latin America, Santiago de Chile: ECLAC.

Escobar Latapi, A. and Gonzalez de la Rocha, M. (2008), 'Survival revisited: women, households and poverty reduction in Mexico', in S. Razavi (ed.), The Gendered Impacts of Liberalization: Towards Embedded Liberalism? London: UNRISD/Routledge.

Esping-Andersen, G., Gallie, D., Hemerijck, A. and Myles, J. (2002), Why We Need a New Welfare State, Oxford: Oxford University Press.

Faur, E. (2009), The "Care Diamond": Social Policy Regime, Care Policies and Programmes in Argentina, Geneva: United Nations Research Institute for Social Development (UNRISD).

Fawcett, B., Featherstone, B. and Goddard, J. (2004), Contemporary Child Care Policy and Practice, Houndmills: Palgrave.

Hall, A. (2008), 'Brazil's Bolsa Familia: a double-edged sword?', Development and Change, 39: $799-822$.

Helgø, C. (2002), 'Market-oriented education reforms and social inequalities among the young population in Chile', in L. Haagh and C. Helgø (eds.), Social Policy Reform and Market Governance in Latin America, Houndmills: Palgrave.

Hobson, B. (2006), 'The evolution of the women-friendly state: opportunities and constraints in the Swedish welfare state', in S. Razavi and S. Hassim (eds.), Gender and Social Policy in a Global Context: Uncovering the Gendered Structure of 'the Social', Houndmills: UNRISD/Palgrave.

Illanes, M. A. and Riesco, M. (2007), 'Developmentalism and social change in Chile', in M. Riesco (ed.), Latin America: A New Developmental Welfare State Model in the Making? Houndmills: UNRISD/Palgrave.

Jackson, C. (1996), 'Rescuing gender from the poverty trap', World Development, 24: 489-504.

Jenson, J. (2008), 'Writing women out, folding gender in: the European Union "modernises"', Social Policy, 15: 131-53.

Jenson, J. (2009), 'Lost in translation: the social investment perspective and gender equality', Social Politics, 16: 446-83.

Jenson, J. and Saint-Martin, D. (2003), 'New routes to social cohesion? Citizenship and the social investment state', Canadian Journal of Sociology, 28: 77-99.

Jenson, J. and Saint-Martin, D. (2006), 'Building blocks for a new social architecture: the LEGO paradigm of an active society', Policy and Politics, 34: 429-51.

Junta Nacional de Jardines Infantiles [JUNJI] (2008), Balance de Gestión Integral, Año 2007, Santiago de Chile: JUNJI.

Korpi, W. and Palme, J. (1998), 'The paradox of redistribution and strategies of equality: Welfare State institutions, inequality, and poverty in the western countries', American Sociological Review, 63: 661-87.

Kremer, M. (2006), 'The politics of ideals of care: Danish and Flemish child care policy compared', Social Politics, 13: 261-85.

La Nación (2008), 'Integra cumple cinco días de paro', Santiago de Chile, 25 November 2008, http://www.nacion.cl/prontus_noticias_v2/site/artic/20081124/pags/20081124225615.html

La Tercera (2006), 'Educadoras de Junji amenazan con paro porque no han tenido respuesta a petitorio', Santiago de Chile, 1 December, http://www.quepasa.cl/medio/ articulo/o,0,3255_5666_240576568,oo.html

Lister, R. (2003), 'Investing in the citizen-workers of the future: transformations in citizenship and the state under New Labour', Social Policy and Administration, 37: 427-43. 
Macaulay, F. (2006), Gender Politics in Brazil and Chile: The Role of Parties in National and Local Policymaking, Houndmills: Palgrave.

Mahon, R. (2002), 'Child care: toward what kind of "Social Europe"?', Social Politics, 9: 34379.

Matear, A. (2006), 'Barriers to equitable access: higher education policy and practice in Chile since 1990', Higher Education Policy, 19: 31-49.

Melo, M. A. (2007), 'Unexpected successes, unanticipated failures: social policy from Cardoso to Lula', in T. Power and P. Kingston (eds.), Democratic Brazil Revisited, Pittsburgh: University of Pittsburgh Press.

Mesa-Lago, C. (2008), Social Insurance (Pension and Health), Labour Markets and Coverage in Latin America, Social Policy and Development, Geneva: United Nations Research Institute for Social Development (UNRISD).

Mideplan (2006), Encuesta de Caracterización Socioeconómica (CASEN) 2006, www. mideplan.ch/casen, accessed 15 August 2008.

Mideplan (2007), Chile Crece Contigo - Sistema de Proteccion Integral a la Infancia, Dossier informativo para encargados comunicacionales de Ministerios, Servicios, Gobiernos Regionales y Municipalidades.

Ministerio de Hacienda (2007), Informe de Ejecución Trimestral Período 2007: Sistema Chile Solidario, Santiago de Chile, http://www.dipres.cl/574/articles-35381_doc_pdf.pdf

Ministerio de Hacienda (2008a), Evaluación Comprehensiva del Gasto. Junta Nacional de Jardines Infantiles (JUNJI), Fundación Integra y Programa de Educación Preescolar de la Subsecretaria de la Educación, Santiago de Chile.

Ministerio de Hacienda (2008b), Proyecto Presupuesto 2009, Santiago de Chile.

Ministerio de Hacienda (2009), Informe de Finanzas Públicas: Proyecto de Ley de Presupuestos para el Sector Público para el año 2010, Santiago de Chile, http://www.dipres.cl/572/articles50148_IFP_2010.pdf

Mkandawire, T. (2004), 'Social policy in a development context: introduction', in T. Mkandawire (ed.), Social Policy in a Development Context, Houndmills: UNRISD/Palgrave.

Molyneux, M. (2007), Change and Continuity in Social Protection in Latin America - Mothers at the Service of the State? Geneva: United Nations Research Institute for Social Development (UNRISD).

Molyneux, M. (2008), 'The "neoliberal turn" and the new social policy in Latin America: how neoliberal, how new?' Development and Change, 39: 775-97.

Montt, P., Peralta, M. V., Poblete, P., Munoz, A., Pacheco, P., Elacqua, G. and Brunner, J. J. (2005), Potenciar el Talento de Nuestros Niños: Educación Preescolar - Estrategia Bicentenario, Santiago de Chile: Mineduc/Fundacion Integra/JUNJI/Universidad Adolfo Ibañez.

Peng, I. (2009), The Political and Social Economy of Care in the Republic of Korea, Gender and Development Programme Paper No. 6, Geneva: United Nations Research Institute for Social Development (UNRISD).

Perez Ribas, R., Veras Soares, F. and Hirata, G. I. (2008), The impact of CCTs. What We Know and What We Are Not Sure About, Brasilia: International Poverty Centre.

Phillips, A. (2006), “'Really” equal: opportunities and autonomy', Journal of Political Philosophy, 14: $18-32$.

Razavi, S. (1997), 'Fitting gender into development institutions', World Development, 25: 1111-25.

Razavi, S. (1999), 'Gendered poverty and well-being: introduction', Development and Change, 30: 409-33.

Razavi, S. (2007), 'The return to social policy and the persistent neglect of unpaid care', Development and Change, 38: 377-400.

Riesco, M. (2007), El Derrumbe de un Mito: Chile Reforma sus Sistemas Privatizados de Previsión y Educación, Santiago de Chile: CENDA-LOM.

Ruel, M., de la Biere, B., Hallman, K., Quisumbin, A. and Coj, N. (2002), Does Subsidized Childcare Help Poor Working Women in Urban Areas? Evaluation of a GovernmentSponsored Program in Guatemala City, Washington, DC: International Food Policy Research Institute. 
Ruel, M. and Quisumbin, A. (2006), The Guatemala Community Day Care Program, Washington, DC: International Food Policy Research Institute.

Schady, N. (2006), 'Early childhood development in Latin America and the Caribbean', World Bank Policy Research Working Paper, Vol. 3869, World Bank.

Sen, A. (1995), 'The political economy of targeting', in D. van de Walle and K. Nead (eds.), Public Spending and the Poor - Theory and Evidence, Baltimore: Johns Hopkins University Press.

Serrano, C. (2005), 'La familia como unidad de intervención de políticas sociales: Notas sobre el programa Puente - Chile Solidario', in I. Arraigada (ed.), Políticas hacia las familias, protección e inclusión socials, Santiago de Chile: ECLAC.

Staab, S. and Gerhard, R. (2010), Early Childhood Education and Care Policies in Latin America: For women or children or both? Gender and Development Programme Paper No. 8, Geneva: United Nations Research Institute for Social Development (UNRISD).

Umayahara, M. (2006), 'Early childhood education policies in Chile: from pre-Jomtien to post-Dakar', UNESCO, Background paper prepared for the Education for All Global Monitoring Report 2007.

World Bank, IADB and SERNAM (2007), Como capitalizar el potencial económico de Chile ampliando las opciones laborales de la mujer - Diagnostico de genero, Santiago de Chile: WB/IADB/SERNAM. 